\title{
A Reappraisal of the Archaeological Resources Along the Proposed LaGrange Bypass, Alternate Route A, Fayette County,
} Texas

Wayne C. Young

Follow this and additional works at: https://scholarworks.sfasu.edu/ita

Part of the American Material Culture Commons, Archaeological Anthropology Commons, Environmental Studies Commons, Other American Studies Commons, Other Arts and Humanities Commons, Other History of Art, Architecture, and Archaeology Commons, and the United States History Commons

Tell us how this article helped you.

This Article is brought to you for free and open access by the Center for Regional Heritage Research at SFA ScholarWorks. It has been accepted for inclusion in Index of Texas Archaeology: Open Access Gray Literature from the Lone Star State by an authorized editor of SFA ScholarWorks. For more information, please contact cdsscholarworks@sfasu.edu. 


\section{A Reappraisal of the Archaeological Resources Along the Proposed LaGrange Bypass, Alternate Route A, Fayette County, Texas}

\section{Licensing Statement}

This is a work produced for the Texas Department of Transportation (TxDOT) by the report producer. TXDOT and the report producer jointly own all rights, title, and interest in and to all intellectual property developed under TXDOT's contract with the report producer. The report may be cited and brief passages from this publication may be reproduced without permission provided that credit is given to both TXDOT and the report producer. Permission to reprint an entire chapter, section, figures or tables must be obtained in advance from either the Supervisor of the Archeological Studies Branch, Environmental Affairs Division, Texas Department of Transportation, 125 East 11th Street, Austin, Texas, 78701 or from the report producer. 
A Reappraisal of the Archaeological Resources Along the Proposed LaGrange Bypass, Alternate Route A, Fayette County, Texas

Wayne C. Young 


\section{INTRODUCTION}

For a number of years, a proposed bypass around the city of LaGrange in Fayette County, Texas, has been in various planning stages with the ultimate objective of diverting highway traffic from the downtown area. Four possible routes have been studied in recent years, and a decision has now been made to proceed with Route A, the closest route to the city along the city's northern boundary (Fig. 1).

The archaeology section of the State Department of Highways and Public Transportation has been involved in cultural resource surveys along each of the proposed corridors and has located prehistoric archaeological sites on each route. Six sites were located along the proposed Route A. The survey of this route was undertaken in 1977.

Since a number of years have passed since the original survey and the area is starting to develop rather rapidly, a reassessment of the sites and the proposed corridor appeared to be in order. Some changes in both the sites and the corridor were noted and are'detailed in this report.

Testing of these sites was limited since the State has yet to acquire the property and access and testing was limited to the willingness of the various landowners. Intensive testing will be delayed until the State has purchased the appropriate properties.

This reevaluation of the archaeological sites along Route A of the proposed bypass indicated that Site 41FY 111 is the only site with adequate depth to require either intensive testing or excavations. 
This Page Redacted Per THC Policy 
SITE 41FY 107

Archaeological Site 41FY107 was originally located along the western bank of the Colorado River in a large floodplain area. The site is now located about 800 feet west of the river in the midst of several abandoned gravel pits (Fig. 2). Most of the pits in the immediate vicinity of the site have filled with water. Brown's Lake is the largest such pit.

Spoil dirt from these pits has been pushed around a great deal by heavy equipment, and numerous questions crossed the writer's mind regarding what was original ground surfaces and what was tailings from the quarrying operations.

Site 41FY 107 is situated along a small access road connecting the gravel pits, and it originally occurred as a probable quarry site in a very thin rock sand. During the revisitation of this site, almost all of the observed cultural materials were split river cobbles. These were found in direct association with a gravel road crossing the site area.

Shovel tests into the site area revealed no cultural depth, with the deposits consisting of a thin layer of gravel lying on top of dense clays. This site appears to have been destroyed by gravel mining activities. No further research is recommended due to lack of a valid cultural deposit. 


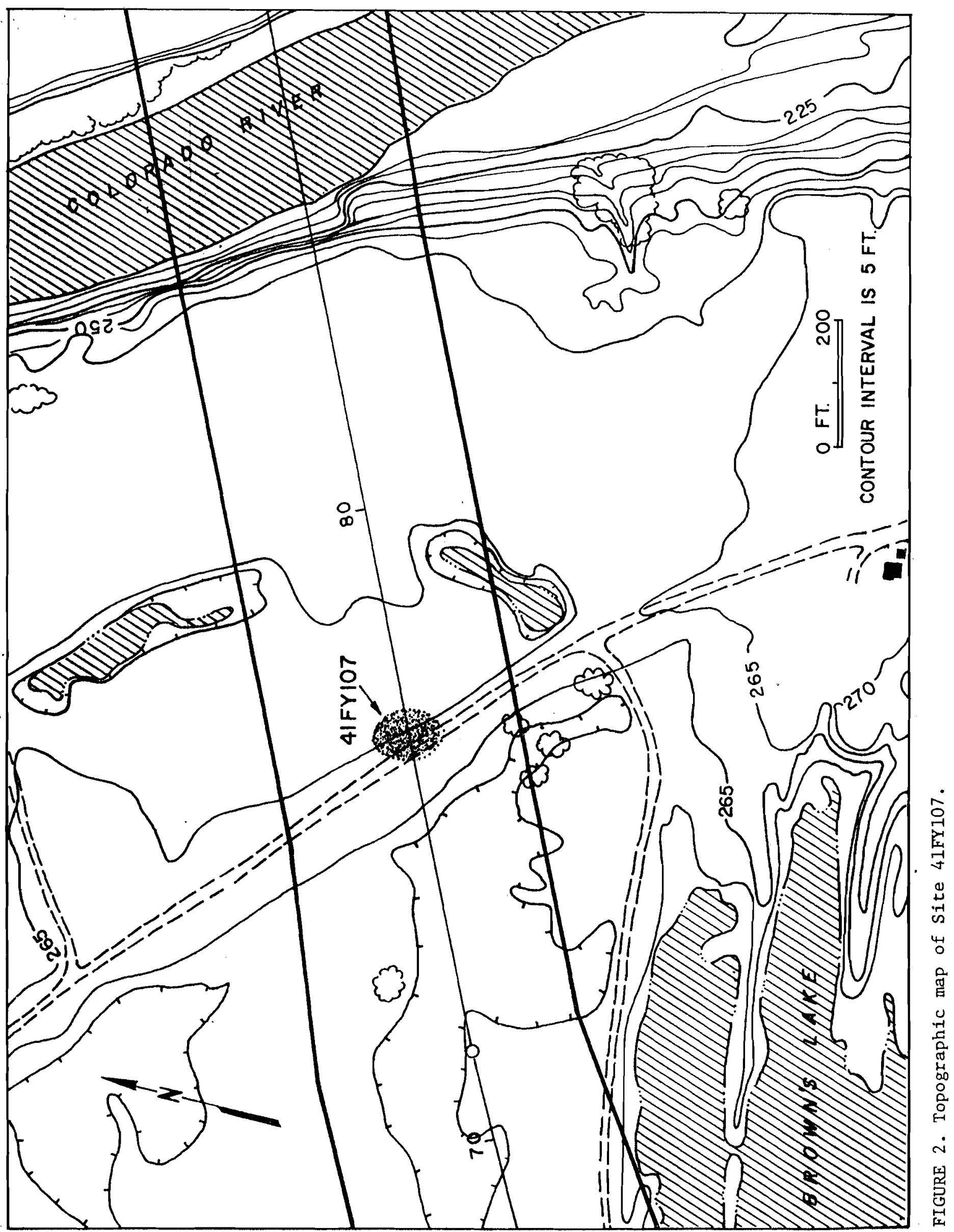


SITE 41FY108

Archaeological Site $41 F Y 108$ is situated along a high ridge line along the eastern aide of the Colorado River (Fig. 3). This ridge line marks the first major change in elevation above the present floodplain. Flint cobbles occurring as gravels are frequent along this ridge line and may represent one of the factors in the selection of this area by aboriginal populations.

The occurrence of gravel in the area has also had considerable influence during historic times. The gravel along the ridge line is near the ground surface and has been extensively mined to an approximate depth of $3 \mathrm{ft}$. across the entire site area. Two large live oak trees were left pedestaled during the quarry operations, and the bases of their trunks are about $3 \mathrm{ft}$. above the present ground surface.

Seven small shovel tests or slit trenches were excavated into the site area to determine if any subsurface cultural materials remained. All of these tests revealed a very thin layer of gravel overlying a dense red clay devoid of prehistoric cultural debitage. The entire site appears to have been removed in quarry operations in the 1950 s.

The present property owner has several artifacts which he collected from the site over the years. These consisted of thick biface fragments, manos, and hammerstones. The site appears to have been exploited primarily as a quarry or lithic procurement area with some habitation also occurring there. Surface materials observed during the reassessment of the site consisted of widely scattered decortication flakes.

Due to lack of depth and the heavy disturbance caused by historic gravel quarrying activities, additional research at Site $41 F Y 108$ appears to be unwarranted. 


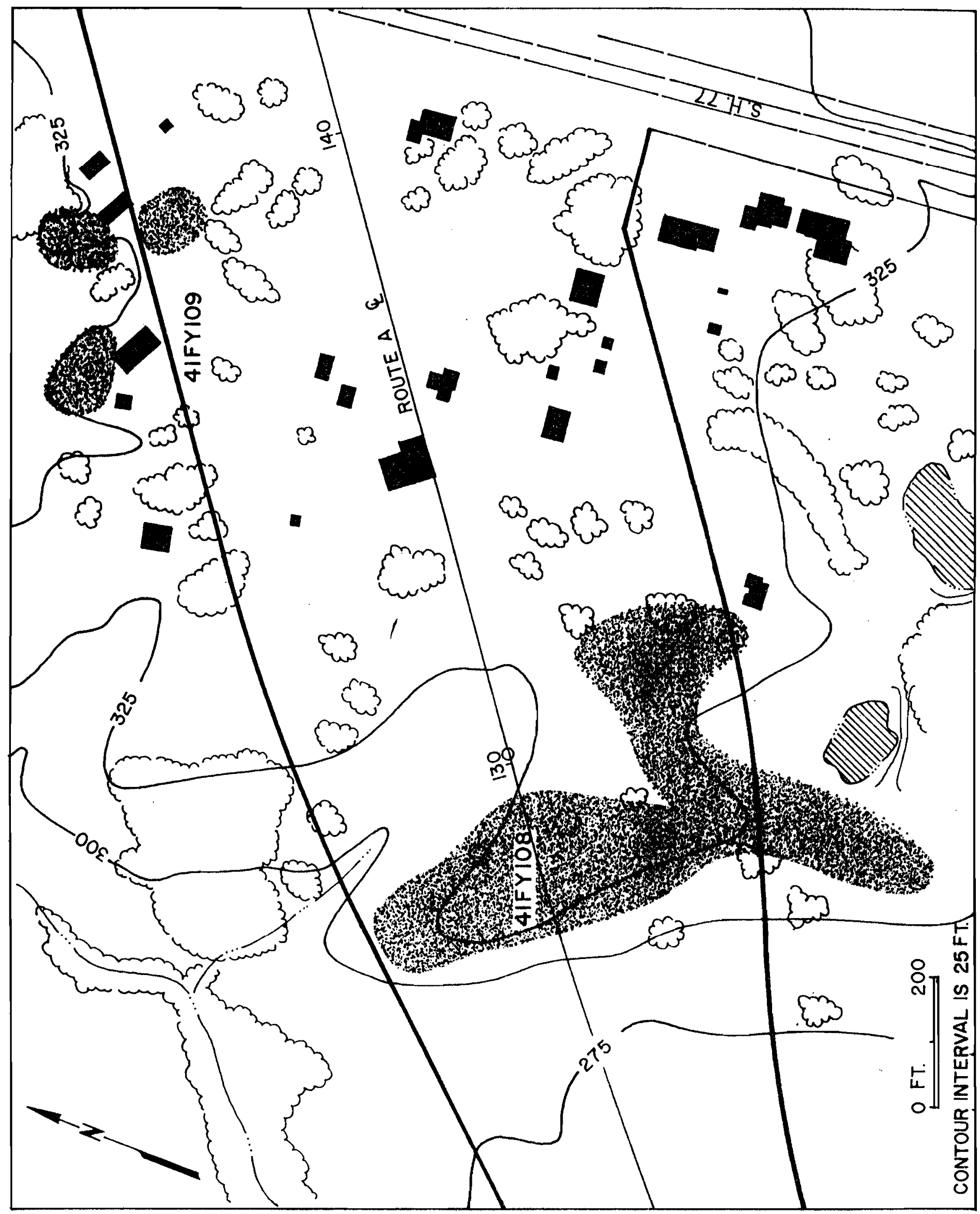


Archaeological Site 41FY109 is situated about 500 feet north-northeast of Site 41FY108 and is on the same ridge line (Fig. 3). The original survey of this site indicated three discrete clusters of prehistoric cultural debris within the proposed right-of-way. All of the areas are reported as being associated with quarrying and lithic reduction activities.

The proposed right-of-way has been realigned since the survey in 1977 and two of the three areas of the site now are located outside of the rightof-way. The remaining area was examined and found to be a thin gravel deposit buried under a midden of Dodge pickup trucks. That portion of the site belongs to a Mr. Kappler, a bulldozer operator, who reported using this portion of the site as an area to test his equipment. A slit trench dug into the 'gravels indicated that no depth was $1 \mathrm{e}$ t to the deposits.

Further work is not proposed for Site 41FY109 due to disturbed deposits and the realignment of the proposed right-of-way. 


\section{SITE 4 IFY 110}

Archaeological Site 41FY110 is located near Tanyard Spring, a tributary of Cedar Creek (Fig. 4). The site is located along the higher bank of the spring atop a gravel deposit. Soils at the site are thin and sandy.

During the original survey of the site, it was noted that at least half of the site would fall outside the proposed right-of-way. Due to a realignment of the corridor area, a 11 of Site $41 F Y 110$ will be spared from construction and no damage should occur to the site. The new alignment places the site south of the project limits. Additional research is not proposed by the Department as the site now lies outside our jurisdiction.

An examination of the site area indicates that it has little depth for separating components and that the primary activity performed there appears to have been lithic reduction tasks normally associated with quarry sites. 


\section{SITE 41FY111}

Archaeological Site 4lFY 111 is located along a ridge line between Cedar Creek and Tanyard Spring (Fig. 4). The site appears to cover 3 to 4 acres in a Bermuda grass pasture with scattered cedar and live oak trees. Gopher mounds are common in the right-of-way area and contain numerous flint flakes and burned rock fragments.

Soils consist of a dark gray sand approaching $50 \mathrm{~cm}$ in depth of $\mathrm{flint}$ gravels. The soil mantle appears to be slightly thicker near the crest of the ridge line and gradually tapers to a $5 \mathrm{~cm}$ thick mantle.

Approximately 1 acre of the site is located within the right-of-way and will be intensively tested once the State acquires the property. The site probably will not meet the criteria for inclusion in the National Register of Historic Places due to the abundant gopher disturbances showing on the surface. 


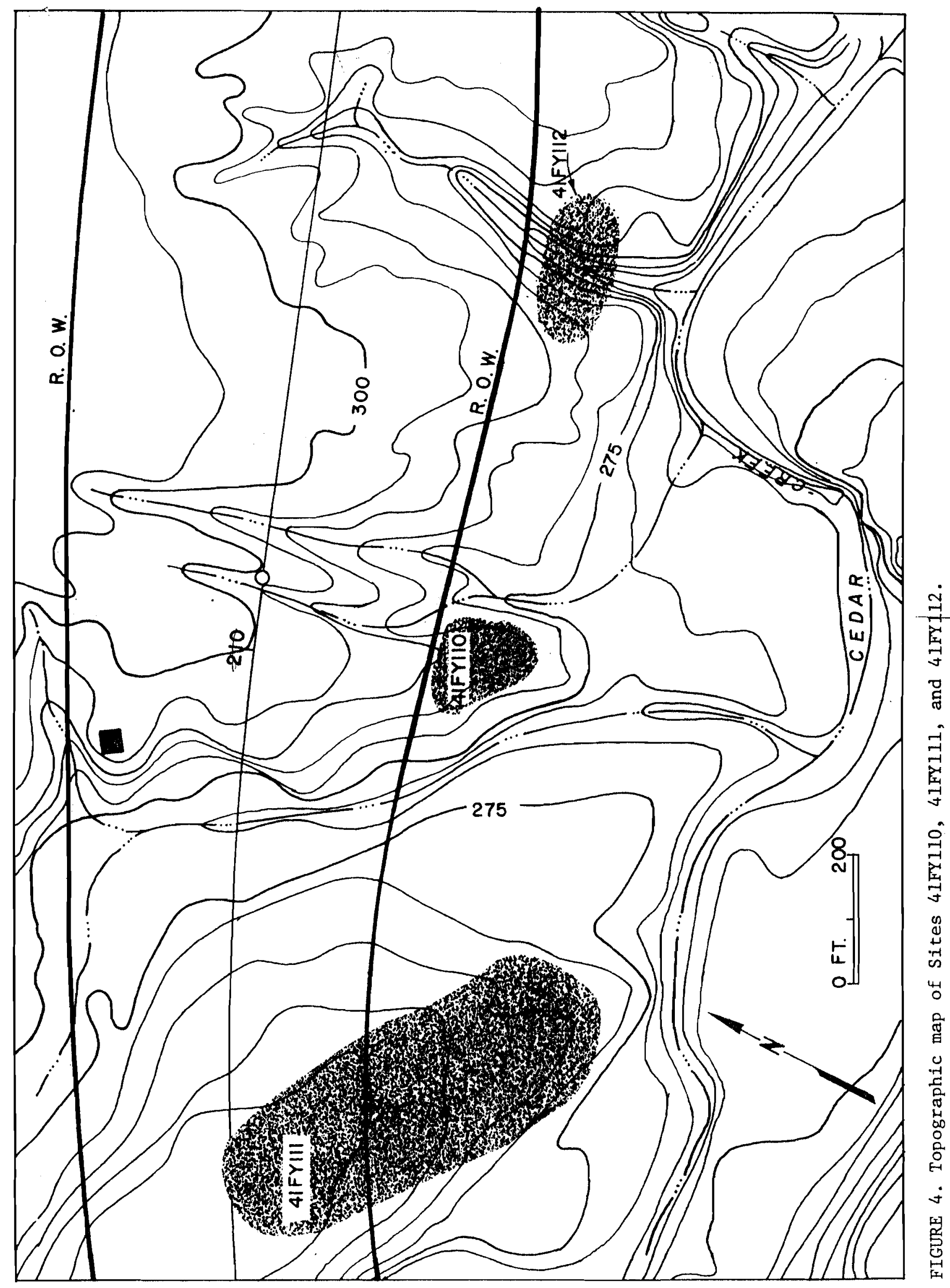




\section{SITE 4 IFY 112}

Archaeological Site $41 F Y 112$ is located along Cedar Creek at a distance of only 500 to $600 \mathrm{ft}$. from Site $41 \mathrm{FY} 110$ (Fig. 4). The site is only $200 \mathrm{ft}$. in diameter along a ridge on the north side of Cedar Creek and a small area across the creek. Diagnostics found during the original survey of the site indicate that it contains a Neo-American component.

This site falls outside the proposed right-of-wayand will not be affected by construction of the proposed bypass project. Due to its 1ocation, no further archaeological research is proposed. 


\section{CONCLUSIONS}

This report.has dealt with six prehistoric archaeological sites located along a proposed bypass route around the northern limits of LaGrange, Texas. A reassessment of the sites once the right-of-way had been firmly established indicated that only one site, 41FY 111, appeared to have sufficient depth to yield any valid archaeological information. The remaining five sites were found to have either been destroyed by historic gravel quarrying or were located outside the right-of-way. 